\title{
COMMENTS ON PLANT-HERBIVORE-PARASITOID INTERACTIONS IN TWO CERRADO AREAS OF SOUTHERN BRAZIL
}

\author{
Astrid Caldas ${ }^{1}$ \\ Fernando de C. Passos ${ }^{2}$
}

\begin{abstract}
This work describes some interactions between lepidopteran larvae and braconid parasitoids on a group of plants at two sites. There was no significant difference in parasitoid diversity between the sites (Shannon index, $p<0.05$ ), and similarity was $62.5 \%$, estimated through Sorensen's index. The diversity of hosts was also not different $(p<0.05)$, but the similarity of host diversity was only $28.5 \%$. This suggests that the parasitoids have strategies for maintaining similar reproduction rates, population densities and communities in areas with different potential hosts.

KEY WORDS. Braconidae, diversity, community, Lepidoptera, similarity
\end{abstract}

In natural systems, the population density of herbivore insects is limited by the density of the plants that are used as food (their food resources) together with the action of their natural enemies (parasitoids, predators and pathogens) (HAIRSTON et al. 1960; HASSEL 1985). Thus, at a certain moment or place, one species density considered low otherwise may have the ideal number of individuals to avoid high levels of predation and/or parasitism, or still to prevent food depletion and consequent intraspecific competition. Besides these, environmental variables such as temperature, humidity and light intensity (among others) usually influence variation of insect population numbers (CLARK et al. 1967; DEMPSTER 1983).

The interactions between different trophic levels is of special importance for the understanding of these processes. In these situations, organisms in one of the levels affect direct or indirectly the other ones (PRICE \& CLANCY 1986). The role of parasitoids, as part of the third trophic level, is therefore an important factor in plant and herbivore dynamics (PRICE et al. 1980; WEIS \& ABRAHAMSON 1985), and any information on their biology and ecology may prove useful.

One of the commonest groups acting as herbivores - thus the second trophic level - is the Lepidoptera. Their larvae feed on various plant families, and the natural control of their populations is usually influenced by parasitoids. These can be found in eggs, larvae, and pupae, and consist mainly of wasps and flies (DEMPSTER 1984). Among the wasps, species of Braconidae are abundant, and this work is concentrated on this family. Their larvae are ecto or endoparasitic, solitary or gregarious, attacking all immature stages of Lepidoptera. They are usually host specific, but generalists also occur.

1) Departamento de Biologia Animal e Vegetal, Universidade do Estado do Rio de Janeiro. Rua São Francisco Xavier 524, 20559-900 Rio de Janeiro, Rio de Janeiro, Brasil.

2) Pós-graduação em Ecologia e Recursos Naturais, Universidade Federal de São Carlos. 13569-905 São Carlos, São Paulo, Brasil. 
Considering the importance of parasitoids and herbivores in tropical systems, this work describes some interactions of herbivores and parasitoids on a group of plants at two sites, with some comments on the similarity of diversity between them.

\section{MATERIAL AND METHODS}

The study sites were Canchim Farm (EMBRAPA, São Carlos, $22^{\circ} 00^{\prime} \mathrm{S}$ and $47^{\circ} 52^{\prime} \mathrm{W}$ ) and the Jataí Ecological Reserve (Luis Antonio, $21^{\circ} 33^{\prime} \mathrm{S}$ and $47^{\circ} 41^{\prime} \mathrm{W}$ ), São Paulo state. Canchim is a somewhat disturbed semideciduous subtropical moist forest, more exuberant and humid, with higher canopy, when compared with Jataí, which is a typical cerrado. The sites have similar climatic patterns, with a dry season from June to September, but with different intensities.

Weekly collections were made by FCP in alternate sites, from February to November 1987. Plants on a $1000 \mathrm{~m}^{2}$ area plot in each site were searched for the presence of herbivores. Larvae were collected with "umbrellas" and direct manual collection on plants carrying herbivores. The "umbrella" was put upside down under the plants, which were shaken in order to dislodge the individuals. Each plant was numbered and the larvae associated to them noted, and samples of the plants were taken to the laboratory both for identification and to feed the larvae.

Individual larvae were reared in glass jars, and parasitoids emerging from them were put in Dietrich solution. When there were no parasitoids, the lepidopteran adults emerged were spread and kept for identification. Unfortunately, definitive identification of some species was not possible because it was not possible to contact the taxonomic specialists that were needed. Because the data about the level of parasitism were still accurate, these results are worth publishing even with the incomplete identifications. In some cases, as with Actinote sp., there may have been more than one species, but because parasitoids tend to be consistent within similar species, the analyses are still worth publishing as a note.

Diversity of parasitoid and herbivore fauna was measured at each site with Shannon's equation and the difference between them was tested through a Student's test proposed by Hutcheson. Similarity between the areas, both for parasitoids and herbivores, was calculated through Sorensen's index (all in MAGURRAN 1988). Frequency data were used to calculate and test the diversity between the two areas. They represent the absolute number of occurrences of parasitism, not the number of parasitoids emerged from a host. This intends to eliminate biases due to gregarious or polyparasitic species.

\section{RESULTS AND DISCUSSION}

The number of collected larvae decreased throughout the study period. Seasonality was already described for Fountainea ryphea (Cramer, [1776]) (Lepidoptera, Nymphalidae) in Campinas, São Paulo, a nearby area (CALDAS 1994, 1995), and seems to be the rule for butterfly species in the region. BROWN (1992) shows seasonality patterns for immatures and adult butterflies at Serra do Japi, a locality about $150 \mathrm{~km}$ southeast of the study sites, mostly related to rainfall. In this 
study, the decrease was probably also the consequence of the collecting effort in the study area, leading to a smaller number of adults emerging. Thus, maybe there was not yet an adult population large enough to maintain the oviposition levels at the sites.

Herbivores with their respective food plants are listed in table I. The parasitoids found in each herbivore are in table II. These parasitoids belong to four braconid subfamilies: Agathidinae, Braconinae, Euphorinae and Microgastrinae, according to ACHTERBERG (1976).

Table I. Sbecies of Lebidontera and their larval food plants.

\begin{tabular}{ll}
\hline \multicolumn{1}{c}{ Lepidoptera } & \\
\hline Actinote sp. & Compositae sp.1 \\
Doxocopa sp. & Piper sp.2 (Piperaceae) \\
& Celtis glycocarpa Mart. (Ulmaceae) \\
Euglyphis sp. & Rapanea umbellata (Mart.) Mez. (Myrsinaceae) \\
& Lithraea molleoides (Vell.) (Anacardiaceae) \\
Fountainea sp. & Croton floribundus Spreng (Euphorbiaceae) \\
Halisidota sp. & Trema micrantha (L.) Blume (Ulmaceae) \\
Hylesia sp. & Croton floribundus Spreng (Euphorbiaceae) \\
& Celtis glycocarpa Mart. (Ulmaceae) \\
& Myrtaceae sp.1 \\
Papilio sp. & Piper sp.1 (Piperaceae) \\
Rosema sp. & Inga sp. (Leguminosae) \\
Tecmessa sp. & Lithraea molleoides (Vell.) (Anacardiaceae) \\
Gelechiidae sp.1 & Croton floribundus Spreng (Euphorbiaceae) \\
Gelechiidae sp.2 & Lithraea molleoides (Vell.) (Anacardiaceae) \\
Hesperiidae sp.1 & Bignoniaceae sp.1 \\
Lasiocampidae sp.1 & Nectandra salicina C.K. Allen (Lauraceae) \\
Notodontidae sp.1 & Eupatorium maximilianii Schrad.exDC (Compositae) \\
Notodontidae sp.2 & Lantana sp. (Verbenaceae); Verbenaceae sp.1 \\
Pyralidae sp.1 & Oxalis rhombio ovata St.-Hil. (Oxalidaceae) \\
Sphingidae sp.1 & Hybanthus atropurpureus (St.-Hil.) Taub (Violaceae) \\
&
\end{tabular}

The frequencies of parasitoids are in tables III and IV. Shannon's index of diversity for parasitoids at Canchim was 0.8423 , and at Jataí was 0.8344 . When compared through Hutcheson's equation for a Student test, no significant difference was found for the parasitism frequency between the sites measured by Shannon's $H^{\prime}(t=0.2643, p<0.05)$. The similarity of these faunas was estimated through Sorensen's equation, and there is a $62.5 \%$ similarity between the areas. This means that, besides having similar species richness (number of species present at each site) and relative abundances, the sites share a high percent of parasitoid species.

The diversity of parasitized hosts was also calculated for both sites. Canchim had a diversity of 0.5866 and Jataí had 0.5066 , also not significantly different from each other at the same level of significance $(\mathrm{t}=1.1365)$. The similarity of host diversity, though, was only $28.5 \%$, which means that the two sites did not share a high percent of herbivores, although they are similarly diverse in terms of species richness and abundance. 
Table II. Parasitoids and their hosts.

\begin{tabular}{ll}
\multicolumn{1}{c}{ Parasitoid } & \multicolumn{1}{c}{ Host } \\
\hline Agathis sp. & Halisidota sp. \\
Apanteles sp. & Hesperiidae sp.1 \\
Bracon $\mathrm{sp}$. & Euglyphis sp. \\
& Fountainea sp. \\
& Gelechiidae sp.1 \\
Cotesia sp. & Fountainea sp. \\
& Hylesia sp. \\
& Sphingidae sp.1 \\
Diocolgaster sp. & Notodontidae sp.2 \\
Distatrix sp. & Doxocopa sp. \\
Glyptapanteles sp. & Actinote sp. \\
& Papilio sp. \\
& Tecmessa sp. \\
& Notodontidae sp.1 \\
& Notodontidae sp.2 \\
Hypomicrogaster sp. & Gelechiidae sp.1 \\
Meteorus sp. & Hylesia sp. \\
& Lasiocampidae sp.1 \\
& Notodontidae sp.2 \\
& Pyralidae sp.1 \\
Parapanteles sp. & Rosema sp. \\
Venanides sp. & Gelechiidae sp.2 \\
\hline
\end{tabular}

Table III: Absolute number of occurrences of parasitoid genera at Fazenda Canchim (site 1) and Reserva Ecológica Jatai (site 2).

\begin{tabular}{lcc}
\hline \multirow{2}{*}{ Parasitoid } & \multicolumn{2}{c}{ Occurrences } \\
\cline { 2 - 3 } & Site 1 & Site 2 \\
\hline Agathis sp. & - & 1 \\
Apanteles sp. & 2 & - \\
Bracon sp. & 3 & 2 \\
Cotesia sp. & 3 & 5 \\
Diocolgaster sp. & 1 & - \\
Distatrix sp. & 1 & - \\
Glyptapanteles sp. & 4 & 2 \\
Hypomicrogaster sp. & 2 & 1 \\
Meteorus sp. & 4 & 2 \\
Parapanteles sp. & - & 3 \\
Venanides sp. & - & 1 \\
\hline Total & 20 & 17 \\
\hline
\end{tabular}

Although the similarity of hosts between the areas was low, the similarity of parasitoids was high. This suggests that the parasitoids have strategies for maintaining similar reproduction rates, population densities, and communities even in different areas, with different potential hosts. Among the strategies, probably 
generalist parasitism is one of the main features, allowing the parasitoids to use a wide range of hosts in the absence of a favorite or specific one.

The diversity of the parasitoid fauna and the different parasitizing strategies could be related to the different host densities. Some species - Hylesia sp., Fountainea sp. - were very common, and many parasitoids were found on them. These were either gregarious or individual parasitoids. For instance, although Meteorus sp. parasitizes larvae individually, it has a high level of parasitism on Hylesia sp., which appears at the study area in batches, thus maintaining the parasitoid population level high. On the other hand, if the parasitoid has gregarious habits, even if few larvae are parasitized, the number of adult parasitoids will still be high in the study site. These different strategies work in opposite directions but have the same effect for parasitoid populations. Also, if a parasitoid is gregarious, it can be more specific on its host range preferences, whereas those that parasitize individually would tend to be more generalists in their host range, in order to provide a higher probability of reproductive success.

\begin{tabular}{|c|c|c|}
\hline \multirow{2}{*}{ Parasitoid } & \multicolumn{2}{|c|}{ Occurrences } \\
\hline & Site 1 & Site 2 \\
\hline Actinote sp. & 67 & - \\
\hline Doxocopa sp. & 5 & - \\
\hline Euglyphis sp. & 1 & - \\
\hline Fountainea sp. & 66 & 22 \\
\hline Halisidota sp. & - & 37 \\
\hline Hylesia sp. & 257 & 135 \\
\hline Papilio sp. & 11 & - \\
\hline Rosema sp. & - & 5 \\
\hline Gelechiidae sp. 1 & 8 & 7 \\
\hline Gelechiidae sp.2 & - & 2 \\
\hline Hesperiidae sp.1 & 1 & - \\
\hline Lasiocampidae sp.1 & - & 1 \\
\hline Notodontidae sp.1 & - & 2 \\
\hline Notodontidae sp. 2 & 6 & - \\
\hline Pyralidae sp.1 & 2 & - \\
\hline Sphingidae sp. 1 & 1 & - \\
\hline Total & 425 & 211 \\
\hline
\end{tabular}

The fact that Croton floribundus Spreng had the highest number of associated herbivores and parasitoids seems to corroborate the hypothesis of ZWÖLFER (1987), which relates the herbivore fauna with the distribution area of the food plant. Because C. floribundus is very abundant and has a higher biomass in the study areas, varying in size from seedlings to trees up to several meters high, it may have a more diverse herbivore fauna associated to it. This fauna, in turn, would represent more options of hosts for generalist parasitoids. 
ACKNOWLEDGMENTS. The authors thank Dr. Angélica Maria P.M. Dias for the identification of braconids and for constant and invaluable advise to FCP during senior thesis, and Dr. Manoel Martins Dias Filho for identification of the herbivores whenever possible. Gerardo Lamas and R.K. Robbins made comments on the manuscript. The Instituto de Florestas and SEMA of São Paulo state allowed the project to be developed at the areas. This work was partially funded by a FAPESP undergraduate fellowship to FCP (87/1170-0), under the sponsorship of Dr. Angélica Maria P.M. Dias.

\section{REFERENCES}

ACHTERBERG, C. VAN. 1976. A preliminary key to the subfamilies of the Braconidae (Hymenoptera). Tijdschr. Ent. 119 (3): 33-78.

BRown, K.S. JR. 1992. Borboletas da Serra do Japi: diversidade, habitats, recursos alimentares e variação temporal, p.142-187. In: L.P.C. MoREllato (Ed.). História natural da Serra do Japi. Ecologia e preservação de uma área florestal no Sudeste do Brasil. Campinas, Editora UNICAMP, $321 \mathrm{p}$.

CALDAS, A. 1994. Biology of Anaea ryphea (Nymphalidae) in Campinas, Brazil. J. Lepid. Soc. 48 (3): 248-257.

1995. Population ecology of Anaea ryphea (Lepidoptera: Nymphalidae): immatures at Campinas, Brazil. J. Lepid. Soc. 49 (3): 234-245.

Clark, L.R.; P.W. GeIER; R.D. Hughes; R.F. Morris. 1967. The ecology of insect populations in theory and practice. London, Chapman and Hall, 232p. DEMPSTER, J.P. 1983. The natural control of populations of butterflies and moths. Biol. Rev. 58: 461-481.

1984. The natural enemies of butterflies, p.97-104.In: R.I. VANE-WRIGHT \& P.R. ACKERY (Eds). The biology of butterflies. London, Academic, 429p.

Hairston, N.G.; F.E. Smith; L.B. Slobodkin. 1960. Community structure, population control and competition. Amer. Nat. 94: 421-425.

HASSEL, M.P. 1985. Insect natural enemies as regulating factors. J. Anim. Ecol. 54: 323-334.

MagurRan, A.E. 1988. Ecological diversity and its measurement. Princeton, Princeton Univ. Press, 179p.

PRICE, P.W. \& K.M. ClanCY. 1986. Interactions among three trophic levels: Gall size and parasitoid attack. Ecology 67 (6): 1593-1600.

Price, P.W.; C.E. Bouton; P. Gross; B.A. McPheron; J.N. Thompson \& A.E. WEIS. 1980. Interactions among three levels: Influence of plants on interactions between insect herbivores and natural enemies. Ann. Rev. Ecol. Syst. 11: 41-65.

WEIS, A.E. \& W.G. ABRAHAMSON. 1985. Potential selective pressures by parasitois on a plant-herbivore interaction. Ecology 66 (4): 1261-1269.

ZWÖLFER, H. 1987. Species richness, species packing, and evolution in insect-plant systems, p. 301-319. In: E.D. SCHUlzE \& H. ZwÖLFER (Eds). Ecological Studies. Potentials and limitations of ecosystem analysis New York, Springer-Verlag, Vol. 61, 435p.

Recebido em 31.VIII.1995; aceito em 10.IX.1996. 